J. Perinat. Med. 14 (1986) 259

\title{
Concentration of free fatty acids (FFA) in amniotic fluid and maternal and cord serum in cases of intrauterine growth retardation
}

\author{
Jan Urban and Anna Iwaszkiewicz-Pawłowska
}

Clinic of Perinatology, Institute of Obstetrics and Gynecology, Medical School, Białystok, Poland

\section{Introduction}

At present, one of the most pressing problem in perinatology is, apart from premature birth, intrauterine growth retardation (IUGR). Its high incidence, the high mortality and psychophysical disorders of children born of pregnancies in which this complication occurred present obstetricians and neonatologists with the task of solving this problem now. This opinion is supported by the data given by DEPP [1], $36 \%$ of stillbirths represented retarded development of the fetus, in $25 \%$ this syndrome is the cause of death in utero, whereas, in $18 \%$ it is the cause of perinatal mortality. Asphyxia during parturition is three times more frequent in fetuses with the IUGR syndrome than in normal pregnancies. As a result of chronic malnutrition, disturbances in the carbohydrate and fat balance occur. In newborns with this syndrome, a decreased level of glucose together with a higher level of free fatty acids in blood serum is found in most cases $[3,4,6,7,9,10]$. Dystrophic cases have a lower resistance to bacterial and viral infection [5, 7], retarded physical development and poor score of intelligence $[2,8]$.

To date, there are no efficacious methods of diagnosing this syndrome before birth, hence therapeutic and prophylactic procedures are practically not available. Since only about $50 \%$ of cases with intrauterine growth retardation

\section{Curriculum vitae}

JAN URBAN was born in 1936, Grodno and graduated from Medical Academy, Bialystok, Poland in 1960. Since 1960 he has been working in the Institute of Obstetrics and Gynecology Medical Academy, Bialystok. He obtained his degree of Doctor of Medical Sciences in 1961 and was appointed. Asso-

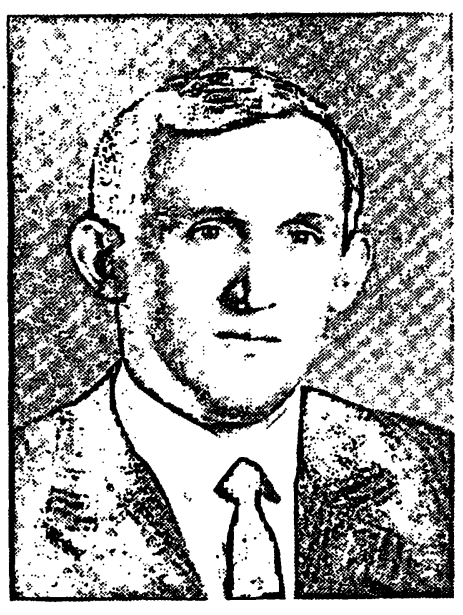
ciate Professor in 1974. Presently he is Head of the Clinic of Perinatology. His main fields of interest are perinatal medicine, especially diagnosis and treatment of prematurity and IUGR.

can be recognized by clinical examination it is necessary to find other methods facilitating diagnosis during pregnancy.

In our investigations, an attempt was made to determine free fatty acid level (FFA) in the amniotic fluid as a biochemical test in prenatal diagnosis.

\section{Materials and methods}

The investigations were carried out in 49 pregnant woman and their newborns in whom the intrauterine growth retardation syndrome of 
the fetus was diagnosed clinically. In addition we measured FFA concentration in 18 parturients. Those were cases from 28 to 32 weeks of normal pragnancy which resulted in spontaneous premature delivery.

The control group consisted of 30 pregnant woman who had an uneventful and normal labor.

Samples of amniotic fluid were taken in the first stage of parturition (dilatation of cervical os $\pm 4-5 \mathrm{~cm}$ ) by technique of vaginal amniocenthesis or amniotomy during cesarian section. Blood samples were taken from the antecubital vein of the parturients immediately after delivery and from the umbilical vein just after clamping of the umbilical cord.

The concentration of free fatty acids (FFA) in the samples of amniotic fluid and serum were determined by the Ducombe method. The results were analyzed statistically by Student's ttest.

\section{Results}

It was found that mean free fatty acid (FFA) concentrations in either amniotic fluid, or maternal serum as well as cord serum of newborns with the IUGR syndrome were higher as compared to controls and premature labor.

The respective values were: in the amniotic fluid $-0.355 \mathrm{mmol} / 1$ and $0.125 \mathrm{mmol} / \mathrm{l}$; in maternal serum - $0.620 \mathrm{mmol} / 1$ and $0.535 \mathrm{mmol} / \mathrm{l}$; in cord serum of the newborns $-0.429 \mathrm{mmol} / 1$ and $0.240 \mathrm{mmol} / 1$ (figure 1).

Particular attention was paid to amniotic fluid concentration of the free fatty acids. It was found that during pregnancy complicated by IUGR, the free fatty acid concentration in the amniotic fluid was almost three times higher than in normal pregnancy $(0.355 \mathrm{mmol} / 1$ and $0.125 \mathrm{mmol} / \mathrm{l}$ ) respectively. This difference is statistically significant $(\mathrm{t}=12.58, \mathrm{p}<0.001)$, FFA concentrations in premature labor group were similar to controls.

Individual results were more differentiated in the IUGR group in comparasion with controls.

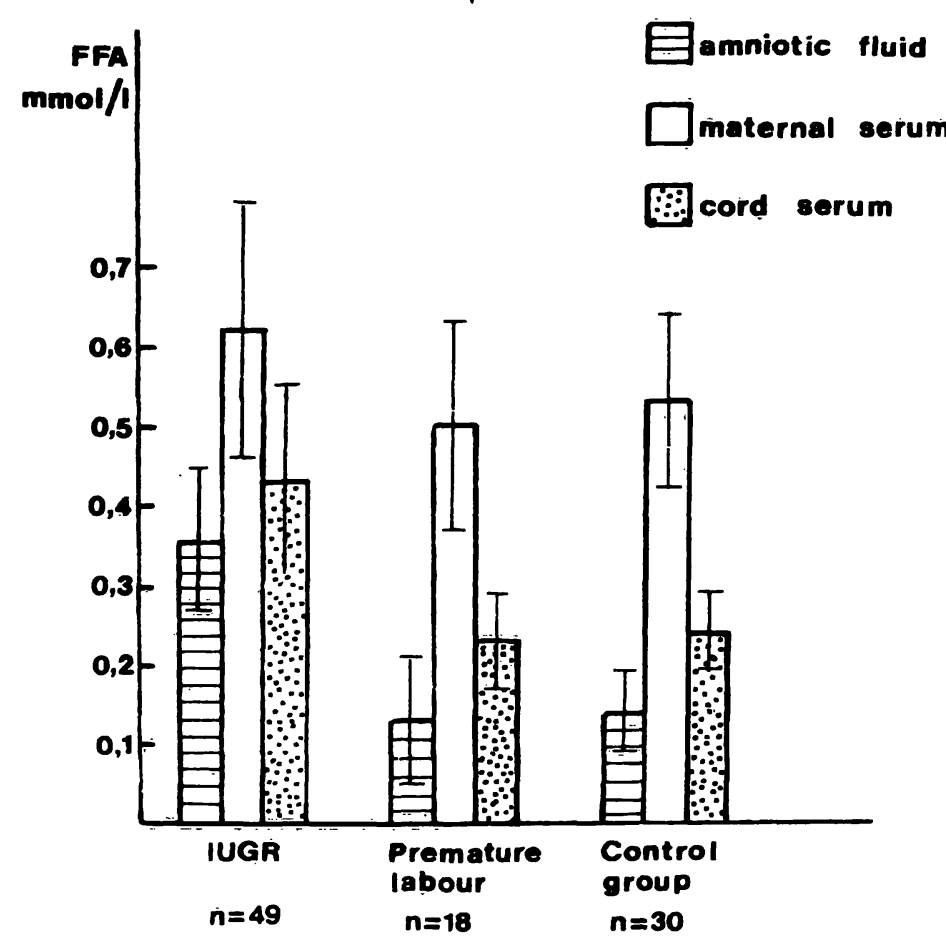

Figure 1. Mean values of free fatty acids (FFA) in amniotic fluid, maternal serum and cord serum.

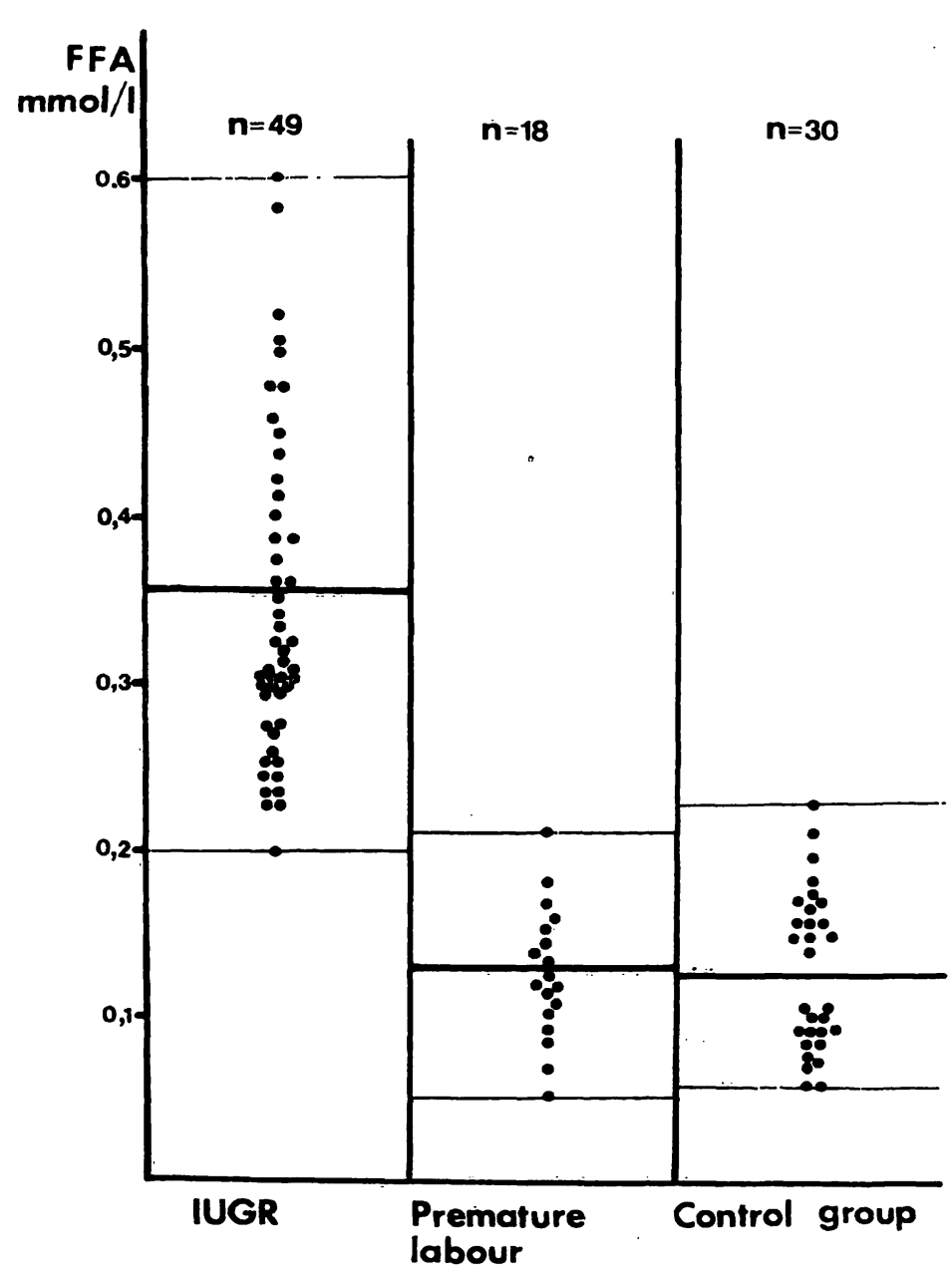

Figure 2. Diagram of individual values of free fatty acids (FFA) in amniotic fluid. 
It could be elucidated by different ethiological factors and various grade of clinical advancement of IGUR (figure 2).

\section{Discussion}

These investigations showed that during pregnancy with the intrauterine growth retardation of the fetus, there is a statistically significant rise of amniotic fluid free fatty acids. Determination of free fatty can be used as a biochemical test in prenatal diagnosis of this syndrome. In addition to other clinical techniques, including ultrasonography, the determination of free fatty acids widens the scope of diagnosis and therapeutic possibilities. Our results permit us to differentiate between prematurity and pregnancies complicated by IUGR.

The behavior of the free fatty acid cocentration in umbilical blood serum of newborns and in the amniotic fluid did not provide an answer to the question as to the source of free fatty acids in amniotic fluid. This source may be fetus or placenta, in particular fetal membranes. Our results may furnish an incentive to investigate the capability of the amnion to synthesize fatty acids and compare the qualitative composition of free fatty acids in the amniotic fluid and the blood serum of the newborn.

\section{Summary}

There are no efficacious methods of diagnosing the syndrome of intrauterine growth retardation (IUGR) before birth. Only about $50 \%$ of cases with this syndrome can be recognized by clinical examinations. The aim of our investigations was an attempt to determine free fatty acid level (FFA) in amniotic fluid as a biochemical test in prenatal diagnosis.

The investigations were carried out in 49 pregnant women and their newborns in whom IUGR was diagnosed clinically. The control group consisted of 30 pregnants who had an uneventful pregnancy and normal labor. Samples of amniotic fluid were taken in the first stage of parturition (dilatation of cervical os $\pm 4-5 \mathrm{~cm}$ ) by vaginal amniocenthesis or amniotomy during cesarian section. The concentration of FFA in samples of amniotic fluid and serum were determined by Ducombe's method.

It was found that during pregnancy complicated by IUGR, the free fatty acid concentration in amniotic fluid was almost three times higher than in normal pregnancy $(0.355 \mathrm{mmol} / 1$ and $0.125 \mathrm{mmol} / \mathrm{l})$ respectively. These differences are statistically significant $(t=12.58$ $\mathrm{p}<0.001$ ). Thus, determination of FFA can be used as a biochemical test in prenatal diagnosis of IUGR.

Keywords: Amniotic fluid, free fatty acids, intrauterine growth retardation, maternal and cord serum.

\section{Zusammenfassung}

Konzentration freier Fettsäuren im Fruchtwasser und im mütterlichen Serum sowie Nabelvenenblut bei intrauteriner Wachstumsretardierung

Es gibt keine effizienten Methoden zur Diagnose einer intrauterinen Wachstumsretardierung (IUGR). Nur etwa 50\% der Fälle können durch klinische Untersuchungen erfaßt werden. Ziel unserer Studie war die Erarbeitung eines biochemischen Tests zur pränatalen Diagnose einer IUGR über die Bestimmung der freien Fettsäuren (FFA) im Fruchtwasser.

Das Untersuchungskollektiv bestand aus 49 Schwangeren bzw. deren Neugeborenen, bei denen antenatal eine IUGR klinisch diagnostiziert worden war. In der Kontrollgruppe waren 30 Frauen mit unkomplizierter Schwangerschaft und normalem Geburtsverlauf. Die
Fruchtwasserproben wurden in der Eröffnungsperiode (bei einer Muttermundsweite von $4-5 \mathrm{~cm}$ ) durch vaginale Amniozentese oder durch Amniotomie bei der Sectio caesarea gewonnen. Die FFA-Konzentrationen im Fruchtwasser und im Serum wurden nach der Methode von Ducombe bestimmt.

Es zeigte sich, daß bei Vorliegen einer IUGR in der Schwangerschaft die FFA-Konzentration im Fruchtwasser im Vergleich zur Kontrollgruppe fast dreifach erhöht waren $(0.355 \mathrm{mmol} / \mathrm{ml}$ versus $0.125 \mathrm{mmol} / \mathrm{ml})$. Dieser Unterschied ist statistisch signifikant $(t=12.58$, $\mathrm{p}<0.001$ ). Die Bestimmung der FFA kann daher als biochemischer Test zur pränatalen Diagnose einer IUGR eingesetzt werden.

Schlüsselwörter: Freie Fettsäuren, Fruchtwasser, intrauterine Wachstumsretardierung, mütterliches Serum und Serum aus der Nabelschnur. 


\section{Résumé}

Concentration en acides gras libres dans le liquide amniotique, le serum maternel et dans le cordon en cas retard de croissance intra-utérin

Il n'y a pas de méthodes efficaces de diagnostic du syndrome de retard de croissance intra-utérin (R. C. I. U.) avant la naissance. On ne peut reconnaitre que environ $50 \%$ des cas de R. C. I. U. par l'examen clinique. Le but de nos travaux est d'essayer de déterminer si les taux d'acides gras libres (F. F. A.) dans le liquide amniotique peuvent être un test biochemique de diagnostic prénatal.

Les examens ont été effectués chez 49 femmes enceintes et leurs nouveaux-nés chez lesquels le diagnostic de R.C.I.U. avait été porté cliniquement. Le groupe contrôle comportait 30 femmes enceintes ayant eu une grossesse sans problème et un accouchement normal.
On a prélevé des échantillons de liquide amniotique au cours de la phase de dilatation (à une dilatation cervicale de 4 à $5 \mathrm{~cm}$ ) par amniocenthèse par voie vaginale ou lors de l'amniotomie au cours des césariennes. On a dosé le taux de F. F. A. du liquide amniotique et du sérum par la méthode de Ducombe.

On a trouvé qu'au cours des grossesses compliquées de R. C. I. U., la concentration de F. F. A. dans le liquide amniotique est presque trois plus élevée qu'au cours de la grossesse normale $(0,355 \mathrm{mmol} / \mathrm{ml}$ et $0,125 \mathrm{mmol} / \mathrm{ml}$ respectivement). Cette différence est statistiquement significative $(t=12,58 ; p<0,001)$. Ainsi le dosage des F. F. A. peut être utilisé comme un test biochemique de diagnostic prénatal du R. C. I. U.

Mots-clés: Acides gras libres, cordon ombilical, liquide amniotique, retard de croissance intra-utérin, sérum maternel.

\section{References}

[1] DEPP R: Postgraduate course in management of high rise pregnancy. Kraków 1984

[2] FitzhaRdinge PM, EM STEVEN: The small-for-date infant. II Neurological and intellectual sequelae. Pediatrics 50 (1972) 50

[3] FrIedman Z: Essential fatty acids revisited. Am J Dis Child 134 (1980) 397

[4] GóRSKI J: Wykorzystanie žródeł energii w czasie wysiłku u cie,żarnych szczurów. Ginekol Pol 49 (1978) 647

[5] IWASZKo-KRAWCZUK W: Serum lysozyme activity in the small-for-dates newborn. Acta Pediatr Acad Sci Hung 14 (1973) 135

[6] KöNIG S, M VEST, M STAHL: Interrelation of maternal and foetal glucose and FFA. The role of insulin and glucagon. Eur J Pediatr 128 (1978) 187

[7] DE LEEW R, IJ DE VRIES: Hypoglycemia in small for dates newborn infants. Pediatrics 58 (1976) 18

[8] NoRSKA I: Wewnatrzmaciczna dystrofia płodu. PZWL Warszawa 1978
[9] Schultz K, J Mestyan, Gy Soltesz, M Horvath: The metabolic effects of glucagon infusion in normoglycaemic and hypoglycaemic small-for gestational-age infants. I Changes in blood glucose, blood lactate and plasma FFA. Acta Pediatr Sci Hung 17 (1976) 237

[10] Treharne IAL, HW Sutherland, JM Stowers, IS Ross: Maternal plasma glucose and FFA concentration related to infant birth weight. $\mathrm{Br} \mathrm{J}$ Obstet Gynaecol 84 (1977) 272

Received January 28, 1985. Revised December 3, 1985. Accepted January 12, 1986.

Jan Urban, M. D. Clinical Medicine of Perinatology M. Skłodowskiej-Curie 24a 15-276 Białystok Poland 